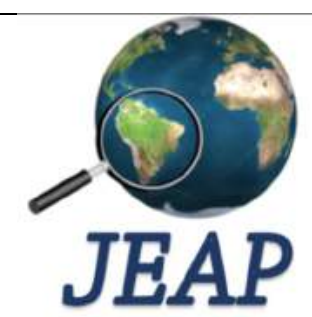

ISSN: 2525-815X

\section{Journal of Environmental} Analysis and Progress

\author{
Journal homepage: www.ufrpe.br/jeap
}

http://dx.doi.org/10.24221/jeap.2.1.2017.1116.72-86

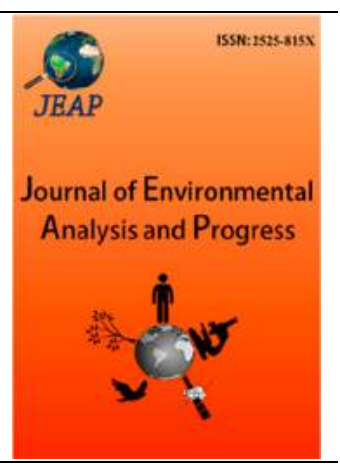

\title{
Vegetation fragment influence over urban climate
}

Tiago Henrique de Oliveira ${ }^{\mathrm{a}}$, Rejane Magalhães de Mendonça Pimentel ${ }^{\mathrm{b}}$, Josiclêda Domiciano Galvíncio $^{c}$

a Programa de Pós-Graduação em Desenvolvimento e Meio Ambiente da Universidade Federal de Pernambuco-UFPE, Gerente de Análise e Geoprocessamento do Instituto da Cidade Pelópidas Silveira, SEPLAN/PCR. Rua do Bom Jesus, n. 227, Bairro do Recife, Recife-PE, Brasil. CEP: 50030-170. E-mail: thdoliveira50@ gmail.com.

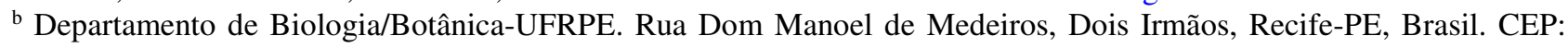
52171-900. E-mail: rejanemmpimentel@gmail.com.

${ }^{\text {c }}$ Departamento de Ciências Geográficas-DCG-UFPE. Av. Prof. Moraes Rego, n. 1235, Cidade Universitária, Recife-PE, Brasil. CEP: 50670-901. E-mail: josicleda@gmail.com.

\begin{tabular}{|c|c|}
\hline A R T I C L E I N F O & A B S T RA C T \\
\hline Received 16 Dec 2016 & Vegetated areas are important to provide environmental quality for the human \\
\hline Accepted 10 Jan 2017 & population that lives in the neighborhood and to avoid natural disasters, such as \\
\hline Published 31 Jan 2017 & $\begin{array}{l}\text { erosion processes. The monitoring of forest fragments and green areas in urban } \\
\text { environment is important to an efficient management of the vegetation. This study } \\
\text { aimed to identify the influence of the vegetation over the urban climate. The Leaf } \\
\text { Area Index (LAI), Normalized Difference Water Index (NDWI) and surface } \\
\text { temperature were considered to be used to monitoring the air temperature. Different } \\
\text { vegetation coverture in distinct areas of a big city, as Recife-PE-Brazil, is responsible } \\
\text { for the environmental quality conditions, mainly those related to the air temperature } \\
\text { and humidity, providing comfortable conditions for the human population. It is } \\
\text { indispensable the monitoring these vegetated areas to optimize the quality life in big } \\
\text { cities. }\end{array}$ \\
\hline & Keywords: Forest vegetation, air temperature, humidity, life quality. \\
\hline
\end{tabular}

\section{Introduction}

Vegetated areas are of great importance for intra-urban areas. It can be mentioned the "function of control and prevention of natural disasters caused by erosion processes, such as landslides", as Rossetti et al. (2007), a decrease of intensity of winds and noises, besides the reduction of the temperature and increase of humidity. The authors conclude that, in general, the presence and maintenance of vegetated areas allow the best permeability of intra-urban land, reducing the surface runoff of rainwater, preventing flooding problems and silting of water bodies (Rossetti et al., 2007).

Urban space becomes the object of constant changes and production of space, influenced by economic, social and cultural relations, which are highly dynamic and changeable over the decades (Berman, 1982). The planning of the urban space aiming the prevention of negative impacts, caused by a rapid disorder expansion of the cities and urban densification, becomes a critical activity.

The monitoring of forest fragments and green areas available in the urban environment is an important activity that permits a more efficient management of the vegetation. Factors such as the rate of warming, cooling, the amount of luminosity and the availability of water vapor control the seasonal and daily activities of the several plants and animal species, establish limits for its occurrence and distribution. The greater level of fragmentation of vegetated areas is more susceptible to disturbances that lead to the disappearance of the forest fragment.

Several orbital and airborne systems have aided researchers from around the world in understanding the adverse effects observed in different urban areas mainly influenced by the change of land cover. One of the most used is the 
LANDSAT system, due to its global coverage, free usage, and database with images from the last three decades.

Using the images available by LANDSAT satellite is possible to calculate other biophysical variables such as leaf area index (LAI), surface albedo, surface temperature, long and short wave radiations, radiation balance, and evapotranspiration, among others. The LAI is a biophysical variable that expresses the growth rate of a determined plant community, presenting a close relation with the productivity (Lang \& McMurtrie, 1992; Xavier et al., 2004; Paiva et al., 2009). Thus, LAI is considered the most important biophysical variable directly related to evapotranspiration (Lang \& McMurtrie, 1992; Sellers et al., 1997; Xavier \& Vettorazzi, 2004) and canopy interception of rainfall (Kergoat, 1998; Dijk \& Bruijnzeel, 2001).

Also, other factors such as the rapid waterproofing of extensive areas due to paving and buildings, promote a significant impact on temperature, which may influence the development of conditions in certain plant species or in the forest fragment itself.

Studies, like that performed by Chen et al. (2006), observed the influence of land use change and land cover on surface temperature distribution. The same authors also affirm that the dramatic increase in the urbanization intensified the emergence of the urban heat islands in several areas. The areas of exposed soil and urban area, initially better spatially distributed due to the small number of buildings, over the years, have been more homogeneous, promoting a continuous pattern of islands of heat.

This study aimed to identify the influence of the vegetation over the urban climate using the Leaf Area Index (LAI), Normalized Difference Water Index (NDWI) and surface temperature, contributing to monitoring the air temperature in great cities.

\section{Material and Methods \\ Study area}

The City of Recife (Figure 1), the capital of the State of Pernambuco (PE), is located on the Northeastern coast, in a central position, $800 \mathrm{~km}$ from other two regional metropolises, Salvador and Fortaleza, disputing with them the strategic space of influence in the region (PCR, 2012).

It has a territorial area of $218.50 \mathrm{~km}^{2}$ and a population of 1,537,704 inhabitants, corresponding to $17.48 \%$ of the people of the whole State, and $41.63 \%$ of the Metropolitan Region of Recife (RMR), with demographic density of 6,989 inhabitants. $\mathrm{km}^{-2}$ (IBGE Census, 2010). Currently, the urban area of the City of Recife is currently divided into 94 neighborhoods, 18 micro-regions and six Political-Administrative Regions (RPA), with RPA 2 being the most densely populated.

According to the classification of Köppen (1948), the climate of the City of Recife is As type (hot and humid), with high temperatures and rains of winter and autumn. The vegetation is composed of Atlantic Forest remnants whose main characteristic is a dense vegetation and mangroves in lower areas, under the influence of tidal waters.

\section{Radiometric data}

Eight images of the Thematic Mapper (TM) sensor, orbit, and dots 214/66, onboard the Landsat 5 satellite, obtained from the Image Generation Division (DGI) of the National Institute for Space Research (INPE) were selected. The satellite's dates of passage in the study area occurred on May 9, 1987, September 28, 1989, June 14, 1991, September 8, 2005, August 26, 2006, July 28, 2007, September 6, 2010, and September 25, 2011.

All Landsat scenes were recorded and orthorectified, based on the image provided by the site www.landsat.org, where the image was subsequently cut out for the study area and its surroundings, aiming a better visualization of the soil and land dynamics (Oliveira et al., 2013).

\section{Pre-processing steps of Landsat satellite imagery}

After downloading the images of the selected area, all bands of each Landsat scene were stacked and corrected geometrically, based on the orthorectified image provided by Earth Explorer. Subsequently, the digital numbers of clouds and cloud shadows were excluded by performing a supervised classification, considering that the study region presents a high incidence of clouds, which made it impossible to use dozens of images in the last 25 years.

Then, the image was cut at the edge of the study area, aiming at a better visualization of the spatial dynamics that occurred in the study area. Considering that the survey area is present at different points (points 65 and 66) of the Landsat satellite 214, all the preprocessing and computation of the indices were performed with the isolated images. Each index generated at the end of the process was mosaic.

\section{Calculating surface temperature (Ts)}

Using the pre-processed images of Landsat was calculated the surface temperature (Ts) through the radiometric calibration and reflectance, with equations proposed by Allen et al. (2002), widely used by several authors (Bastiaanssen et al., 
1998ab; Silva et al., 2005; Giongo, 2008; Oliveira

et al., 2010).

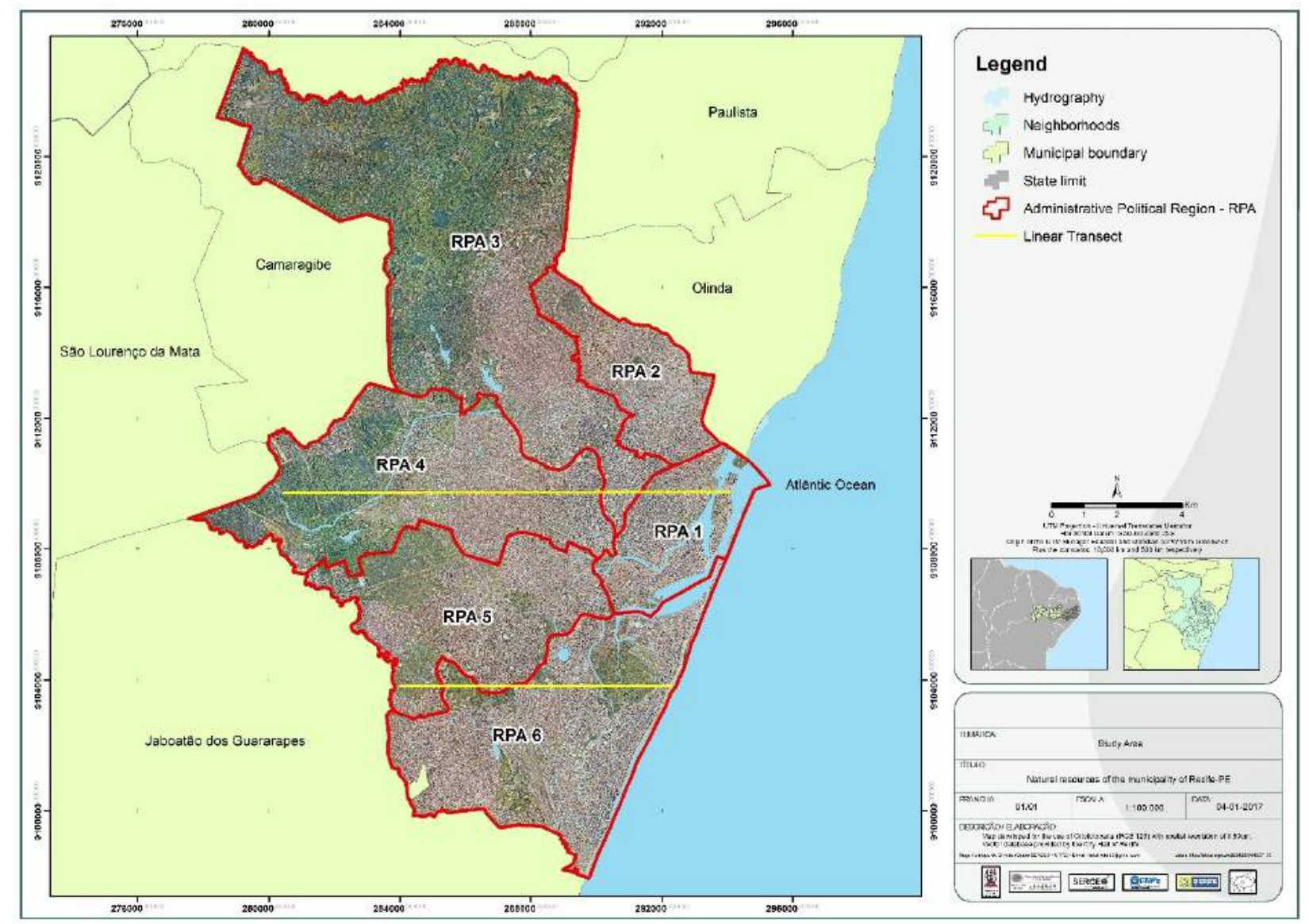

Figure 1. Localization of the City of Recife, Pernambuco State, showing the distribution of the PoliticalAdministrative Regions (RPA). Font: Oliveira (2012).

The radiometric calibration was obtained converting gray levels of each pixel and band, in a monochromatic radiance that represents the solar energy reflected per unit of area, of time, of solid angle, and of wavelength measured at satellite level in the bands $1,2,3,4,5$ and 7 . This radiance, considering the thermal band, represents the radiation emitted by each pixel, and used to obtain the surface temperature, following the equation purposed by Markham \& Baker (1987):

$L_{\lambda i}=a_{i}+\frac{b_{i}-a_{i}}{255} N D$

where $\mathrm{a}$ and $\mathrm{b}$ are the minimum and maximum spectral radiances $\left(\mathrm{Wm}^{-2} \mathrm{sr}^{-1} \mu \mathrm{m}^{-1}\right), \mathrm{ND}$ is the intensity of the pixel (integral value between 0 and 255), and i correspond to the bands $(1,2, \ldots$ and 7$)$ of the Landsat 5 satellites. The coefficients of calibration used to TM images are those purposed by Chander \& Markham (2003).

\section{Reflectance}

The reflectance (Equation 2) of each band $\left(\rho_{\lambda i}\right)$ is defined by the ratio between the reflected solar radiation flux through the surface and the incident global solar radiation flux, which is obtained using this equation (Allen et al., 2002):

$$
\rho_{\lambda i}=\frac{\pi \cdot L_{\lambda i}}{K_{\lambda i} \cdot \cos Z \cdot d_{r}}
$$

where $L \lambda \mathrm{i}$ is the spectral radiation of each band, $\mathrm{K} \lambda \mathrm{i}$ is the spectral solar radiation of each band on the top of the atmosphere $\left(\mathrm{Wm}^{2} \cdot \mu \mathrm{m}^{-1}\right), \mathrm{Z}$ is the solar zenith angle, and dr is the square of the ratio between the Earth-Sun medium distance (ro) and the Earth-Sun distance (r) in a day of the year (DSA).

\section{Soil Adjusted Vegetation Index (SAVI)}

A factor was added to the Normalized Difference Vegetation Index (NDVI) to incorporate the effect of the presence of the Soil Adjusted Vegetation Index (SAVI), obtained through the Equation 3, purposed by Heute (1988), 
maintaining the value of the NDVI between -1 and +1 :

$$
S A V I=\frac{(1+\mathrm{L})\left(\rho_{\mathrm{IV}}-\rho_{\mathrm{V}}\right)}{\left(\mathrm{L}+\rho_{\mathrm{IV}}+\rho_{\mathrm{V}}\right)}
$$

where $\rho_{\mathrm{IV}}$ and $\rho_{\mathrm{v}}$ correspond, respectively, to the near infrared band and of red and $\mathrm{L}$ is the soil factor of adjustment, which value more frequently used is 0,5 (Accioly et al., 2002; Boegh et al., 2002; Silva et al., 2005).

\section{Leaf Area Index (LAI)}

The leaf area index (LAI) inform about the ratio between the leaf areas of whole vegetation by the unit of area used by this vegetation. This index is an indicator of the biomass of each pixel of the image, calculated using an empirical equation purposed by Allen et al. (2002), Equation 4:

$$
L A I=-\frac{\ln \left(\frac{0.69-S A V I}{0.59}\right)}{0.91}
$$

\section{Emissivity}

The surface temperature is obtained using the Planck equation inverted, valid to a blackbody. Whereas each pixel does not emit electromagnetic radiation as a blackbody, is necessary to introduce the emissivity of each pixel in the spectral domain of the thermal band ${ }^{\varepsilon_{\mathrm{NB}}}$, which is: 10.4-12.5 $\mu \mathrm{m}$.

According to Allen et al. (2002), the emissivity $\varepsilon_{\mathrm{NB}}$ (Equation 5) obtained to the NDVI $>0$ and $\mathrm{LAI}<3$ followed:

$\varepsilon_{\mathrm{NB}}=0.97+0.00331 L A I$

each pixel with $\mathrm{LAI} \geq 3, \varepsilon_{\mathrm{NB}}=\varepsilon_{0}=0.98$. Each water body (NDVI $<0$ ), considering the lake of Sobradinho and the riverbed of Rio São Francisco, Silva \& Cândido (2004) used the values of $\varepsilon_{\mathrm{NB}}=$ 0.99 and $\varepsilon_{0}=0.985$, considering Allen et al. (2002).

\section{Surface temperature (Ts)}

The surface temperature was determined through the spectral radiance of the thermal band $\mathrm{L}_{\lambda, 6}$ and the emissivity ${ }^{\varepsilon_{\mathrm{NB}}}$, obtained as in the last step. In this way, the surface temperature is achieved in Kelvin scale applying the Equation 6:

$$
\mathrm{T}_{\mathrm{s}}=\frac{\mathrm{K}_{2}}{\ln \left(\frac{\varepsilon_{\mathrm{NB}} \mathrm{K}_{1}}{\mathrm{~L}_{\lambda, 6}}+1\right)}
$$

where $\mathrm{K} 1=607.76 \mathrm{wm}^{-2} \cdot \mathrm{sr}^{-1} \cdot \mu \mathrm{m}^{-1}$ and $\mathrm{K} 2=$ $1260.56 \mathrm{~K}$ are constant of calibration of the thermal band of the Landsat $5 \mathrm{~T}$ (Allen et al., 2002; Silva et al., 2005).

\section{Normalized Difference Water Index (NDWI)}

The Normalized Difference Water Index inform the moisture content using the Equation 7, obtained through the ration between the differences of reflectivity of the near infrared ( $\rho_{I V P}$ ) and the medium infrared ( $\rho_{N I R}$ ), and the sum of them:

$N D W I=\frac{\rho_{\mathrm{IV}}-\rho_{M I R}}{\rho_{\mathrm{IV}}+\rho_{M I R}}$

where $\rho_{I V P}$ and $\rho_{\text {NIR }}$ correspond, respectively, to the bands 4 and 5 of the Landsat 5 TM. Considering Cardozo et al. (2009), "[...] the vegetation index purposed by Gao (1996) is related to the content of water in the leaves", where negative values represent areas with dry vegetation and positive values the green one.

\section{Results}

It was visible the reduction of the vegetation coverture through the LAI (Figure 3) in several areas of the City of Recife analyzing the image of 1987, as occurred, mainly, in the areas 1 and 6 of the RPA. The areas with hydric corps, like in areas without any vegetation (areas with buildings) and with waterproofed by asphalt, showed values of 0 (zero) of LAI. In exposed soil, the LAI values were near to 0 (zero) in the majority of situations.

LAI values equal to 0 (zero) were obtained in rounded areas in some images, as in 1987, 2005 and 2011, located in an area with vegetation in North of the City of Recife. These areas could be detected after the manual classification and exclusion of clouds or shadows of clouds from the images; it is tough to exclude areas automatically without vegetation.

Extensive areas in the RPA 1 showed values of LAI oscillating from 0 and 0.10 to the image of 1987. The regions with any vegetation more evident, like in the Arsenal Square, in the neighborhood of Recife, presented values of LAI higher than 0.40 . The areas with exposed soil in the neighborhood of Várzea and Curado forest also showed values of LAI equal or near to zero. 
Great avenues, with poor vegetation cover, are more detachable because of the blocks used for commerce, without the use of plants in these sites. It is possible to observe in the image of 2005 that these areas with low LAI values show a crescent development in public and private areas.

Areas with LAI from 0.41 to 0.60 reduced spatially meanwhile LAI values lower than 0.20 increased from the image of 2005. In some situations, the possible existence of a smaller vegetal cover is a result of the spatial resolution of the image, indicating a reduced vegetal cover in the pixel.

Considerable fragments of forest to the west of the municipality, like Várzea, a Dois Irmãos, Mata do Curado and Jardim Uchôa forests showed evident development in the period of this investigation. These areas, public or private, became protective areas; the Mata do Curado is under Brazilian Army protection (Guimarães et al., 2012ab). It was reduced the anthropic disturbance in this area, reducing and allowing the regeneration of several plant species.

These areas, in the image of 1987, showed values of LAI greater than 0.60 and in some sectors inside the fragment from $0.40 \mathrm{~m}$ to 0.60 . Treetops became more homogeneous in the image of 2005, showing values greater than 1.20. Considering the Várzea forest, the areas nearest the margins of the Capibaribe River showed values of LAI higher than 1.50 (Figure 3).

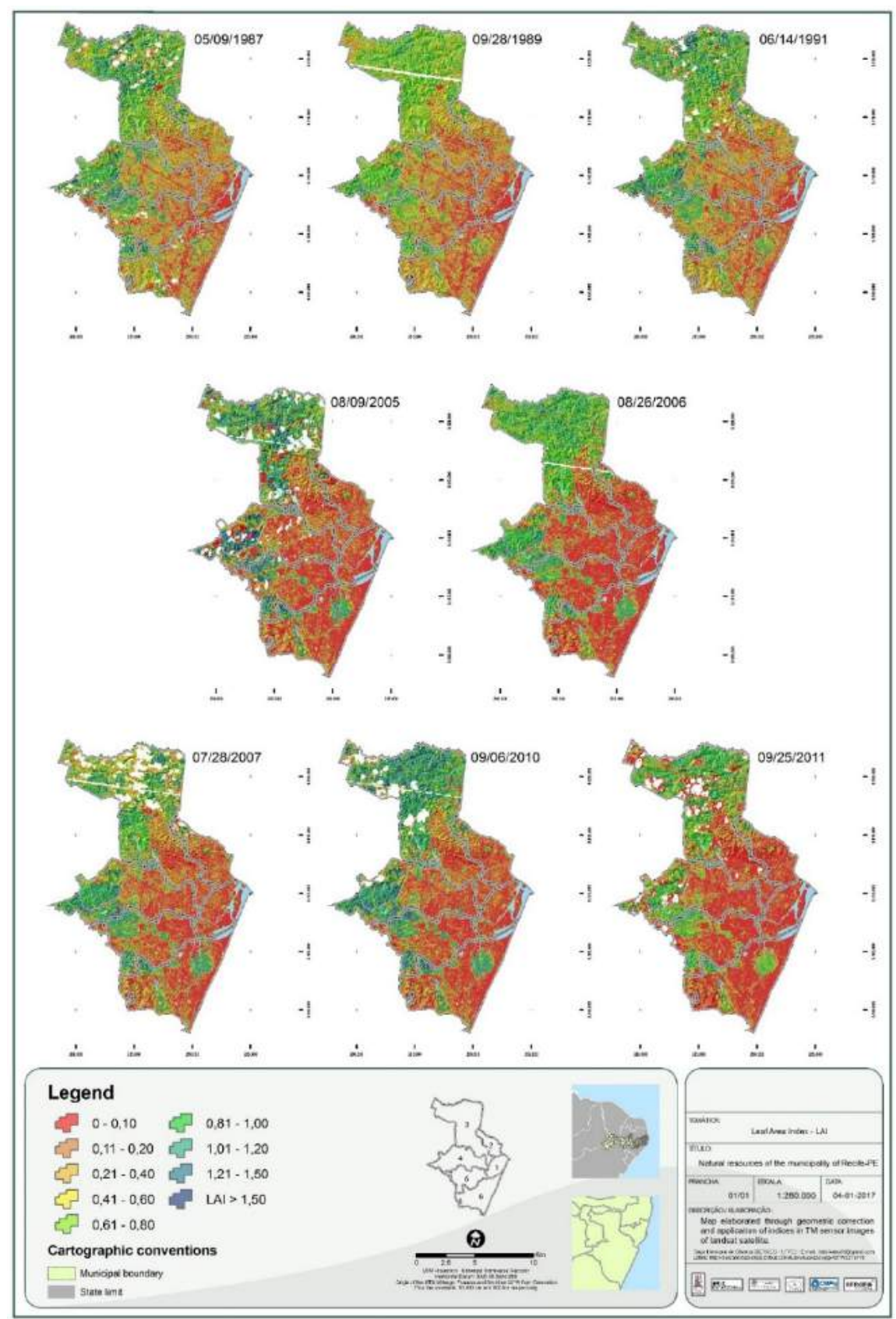

Figure 3. Spatial and temporal evolution of the Leaf Area Index (LAI) in the City of Recife, Pernambuco State. Font: Oliveira (2012). 
Journal of Environmental Analysis and Progress V. 02 N. 01 (2017) 72-86

The NDWI (Figure 4) permit detects the spatial-temporal decreasing of the moisture values and the apparent fragmentation of the Atlantic Forest, more perceptible in the neighborhood of RPA 1, 2 and 6. As a consequence of the process of fragmentation of forest areas, there is an increase in the susceptibility of tree breaking by the wind (Zeng et al., 2009) and a reduction of habitat for forest species. It depends on large fragments (Teixeira et al., 2009) and changes in local microclimatic conditions (Bierregaard \& Dale, 1996 apud Ribeiro et al., 2009).

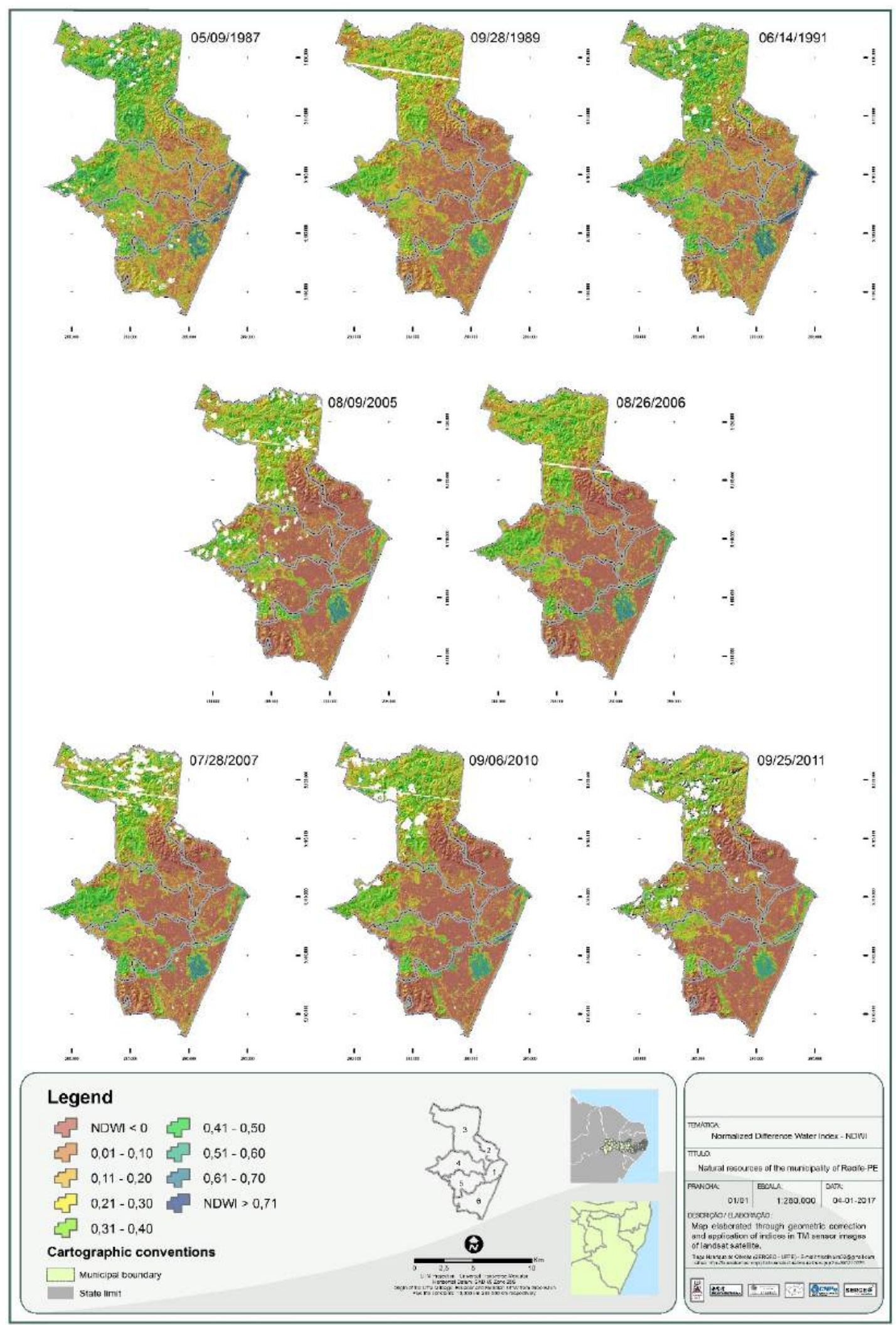

Figure 4. Spatial and temporal evolution of the Normalized Difference Water Index (NDWI) in the City of Recife, Pernambuco State. Author: Oliveira (2012). 
Considering the IAF, the forest fragments, such as Várzea and Dois Irmãos forest, it was possible to maintain high humidity indexes in all images, with NDWI values above 0.30. The riparian areas, as well as the mangrove areas, had higher humidity values, with humidity greater than 0.61 in several sectors. These areas presented a great prominence in the IAF, with values greater than 1.51, observed at the Pina mangrove (Figure $5)$.

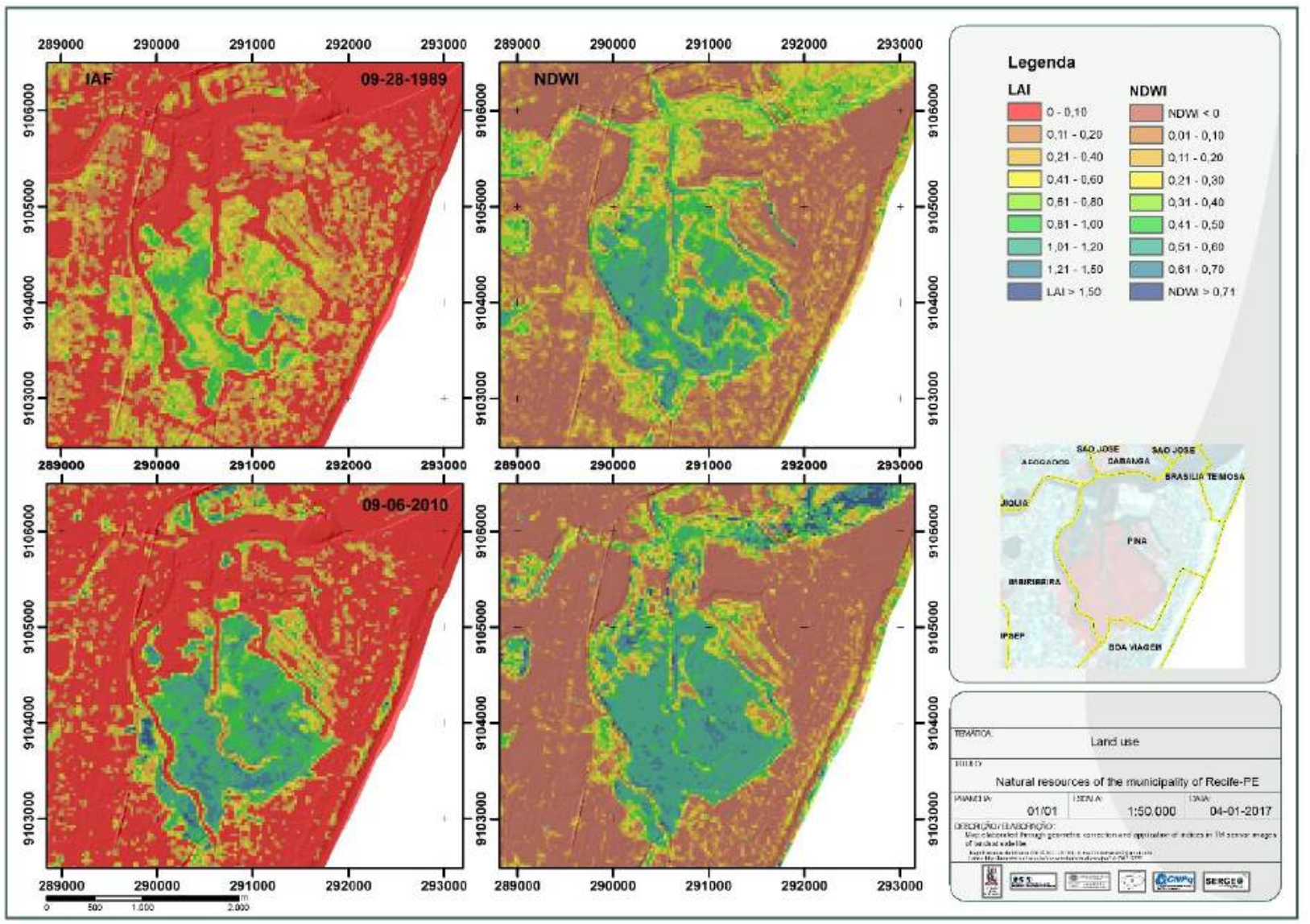

Figure 5. Spatial and temporal evolution of the Leaf Area Index (LAI) and the Normalized Difference Water Index (NDWI) to the mangrove of the neighborhood of Pina, City of Recife, Pernambuco State. Author: Oliveira (2012).

It is observed a great homogenization of values of humidity below zero in most of the districts from the image of 2005. The Special Zones of Social Interest (ZEIS) and the communities, both in flat and with hills present few areas with NDWI values above 0 in most of the cases. These values are due to the high urbanization and the gradual replacement of the vegetation cover with other materials. On the other hand, as in RPA 3, the districts of Nova Descoberta, Vasco da Gama, and Alto José Bonifácio, under major changes in the time of use and land cover, presented NDWI values ranging from lower to zero up to 0.10 to a significant part of its territory (Figure 6).

In the last decades, these neighborhoods have undergone considerable modifications of use. Initially, the population of increased purchasing power, leading to a spontaneous occupation by the neediest population, neglected these areas for occupation. As the most central neighborhoods showed an increase in the value of the city is already populated peripheral neighborhoods, it exhibited high growth rates. The increases occurred between 1991 and 2000 were observed in Cohab (39\%), Barro (57\%), Macaxeira (71\%), Passarinho (76\%) and Caçote \%) (Instituto Polis, 2009). It can be noted that the areas that present high slope in some places of RPA 2 (Figure 6) and RPA 5 are one of the factors that limited the occupation of some regions of these neighborhoods, allowing the established vegetal individuals to develop greater leaf biomass. However, NDWI values were lower than 0 in much of the RPA 2 for images such as 2010 and 2011. 


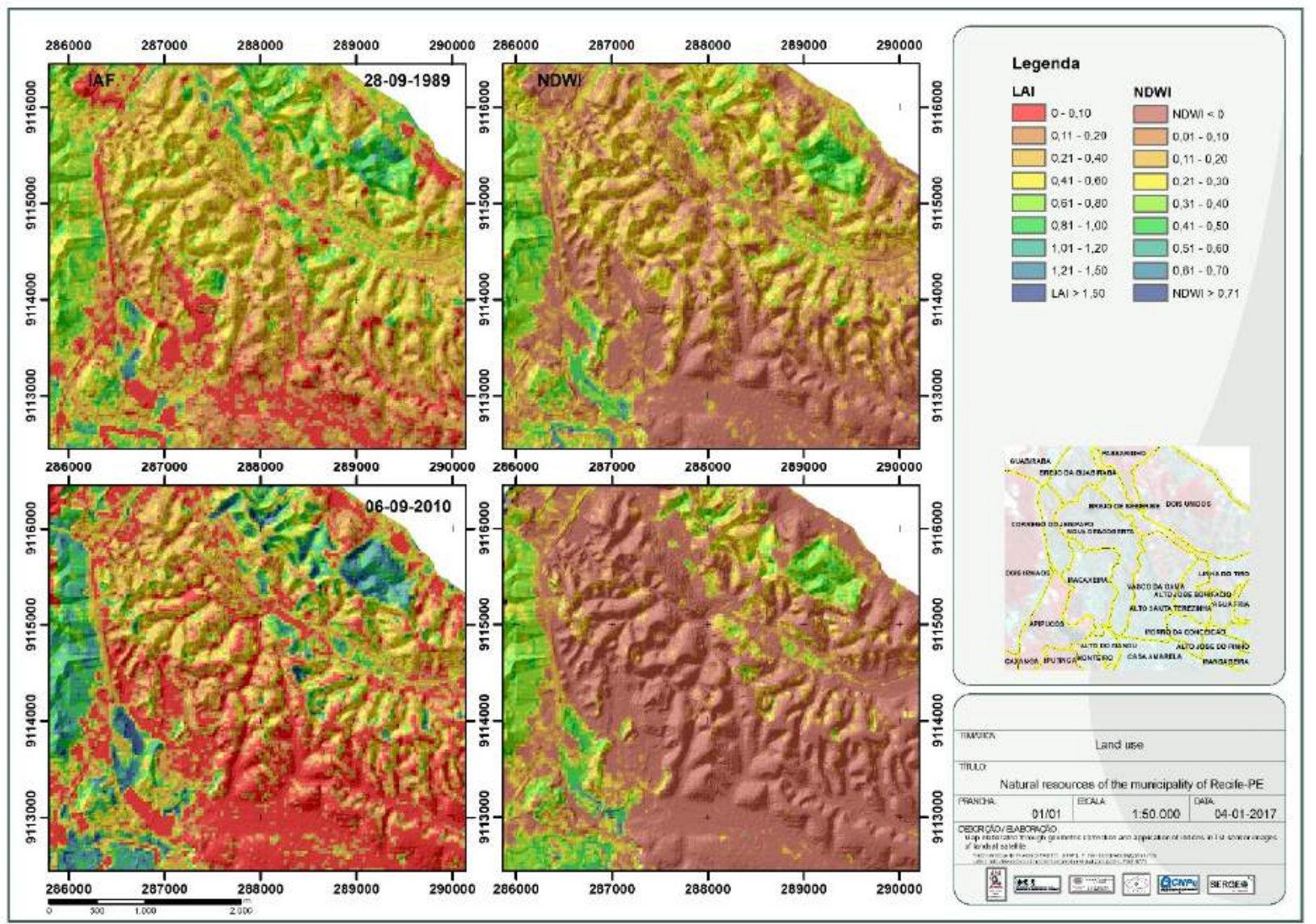

Figure 6. Spatial and temporal evolution of the Leaf Area Index (LAI) and the Normalized Difference Water Index (NDWI) to the neighborhoods of RPA - 3, in the City of Recife, Pernambuco State. Author: Oliveira (2012).

Considering the temperature of the surface - Ts (Figure 7), it can be noticed, as in periods of higher temperatures, that it corresponds to the period from September to February. The vegetated areas, as well as the water bodies, play a major role in the mitigation of temperatures in an urbanized or densified environment.

It is possible to observe a belt with milder temperatures in the northern and western part of the city, wherein wetter periods, temperatures below $23^{\circ} \mathrm{C}$ can be checked, while in drier periods there is a temperature variation between $23^{\circ} \mathrm{C}$ and $26^{\circ} \mathrm{C}$. These regions present as an important factor the forest areas of Guabiraba, Várzea and Curado districts, for example.

Riverbanks, such as the Capibaribe and the Tejipió Rivers, also show high mitigation in the values of surface temperature due to the amount of water released through evaporation and the riparian forest existing in most of these rivers. The areas of exposed soil and urban area, previously spatially distributed over the years, became more homogeneous, formed by a continuous pattern of islands of heat. The centers of high temperatures are consistent with the large areas built and waterproofed.

It is noted that RPA-1 exhibits surface temperature more than $25^{\circ} \mathrm{C}$ in most of its area in almost every year. In the case of the RPA-2, it is possible to observe the significant influence of the change of the use and cover of the ground in the distribution of the surface temperature. The most northwest area of this RPA was able to maintain milder temperatures $\left(\mathrm{Ts}<25^{\circ} \mathrm{C}\right)$ in most of the images used, mainly due to the amount of vegetation currently found in the area.

In wetter periods, as in the images of 1987 , 1991, 2005 and 2007, or drier (verified in other images used in this study), it was observed the recurrence of sites that presented higher temperatures about the surroundings, which can be characterized as islands of heat. These areas are differentiated by the predominance of large sheds and regions with high constructive or waterproof density, which causes a greater absorption and retention of heat when compared with natural environments, for example. 
Journal of Environmental Analysis and Progress V. 02 N. 01 (2017) 72-86

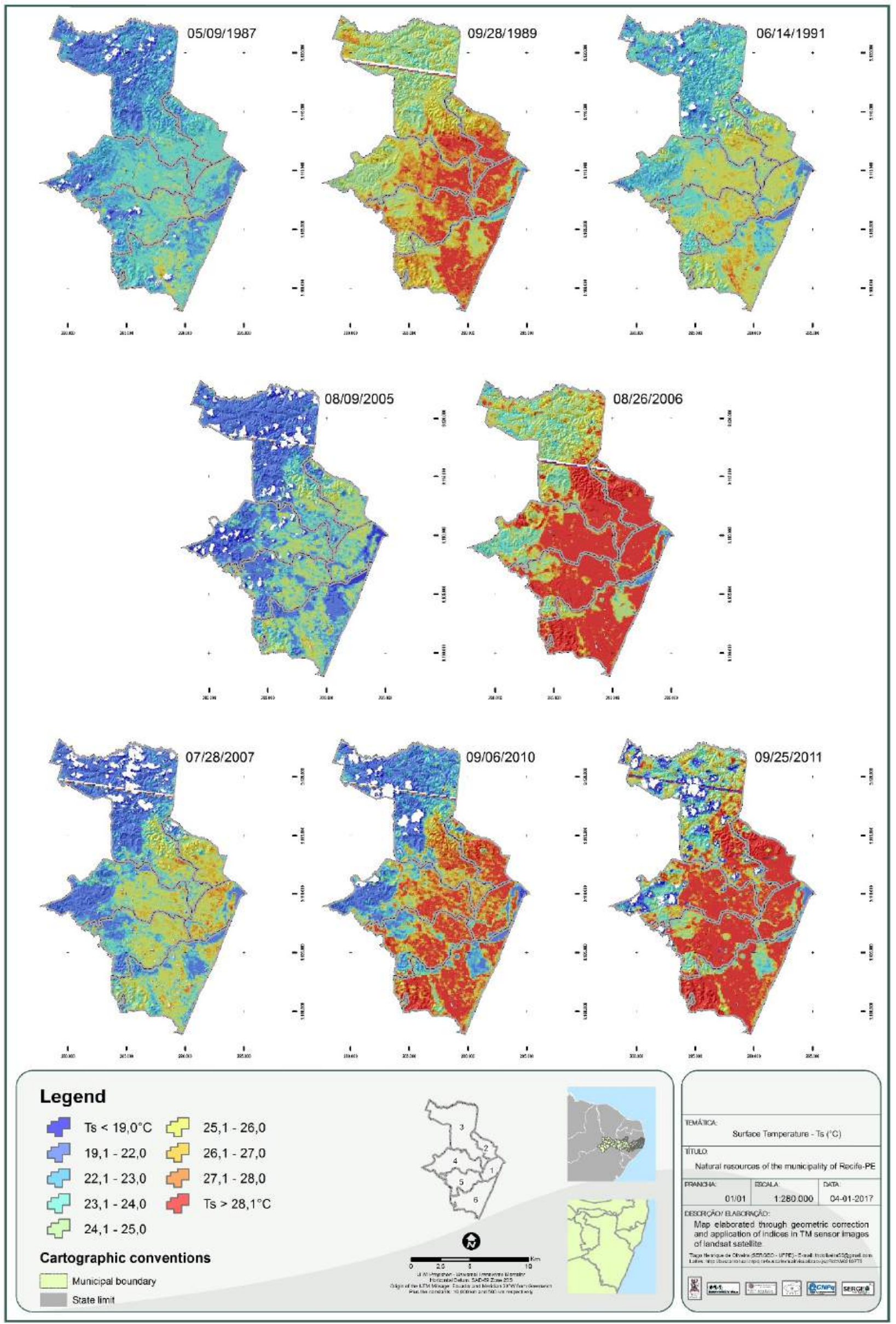

Figure 7. Spatial and temporal evolution of the surface temperature (Ts) in the City of Recife, Pernambuco State. Author: Oliveira (2012). 
Aiming evidence the surface temperature and humidity constructions in vegetated and urbanized areas, graphs of linear transects were drawn in two areas of the city. The Figures 8 to 10 are related to linear transect 1 , which presents the initial point in Mata da Várzea to the Recife neighborhood.

The Figures 11 to 13 are related to the linear transect 2, starting in the Mata do Barro to Boa Viagem beach. The transect 1 (Figures 8, 9 and 10) shows clearly the increase of the thermal amplitude between the years selected in this study, showing a variation of $9^{\circ} \mathrm{C}$ for the image of September 2010, between the forest fragment and the areas more urbanized or built. There is a slight decrease in surface temperature in the Federal University of Pernambuco, due to the greater amount of vegetation present on the Campus of the University. The values of NDWI and LAI presented high values in forest fragments and more vegetated areas and marked decrease in urban areas.

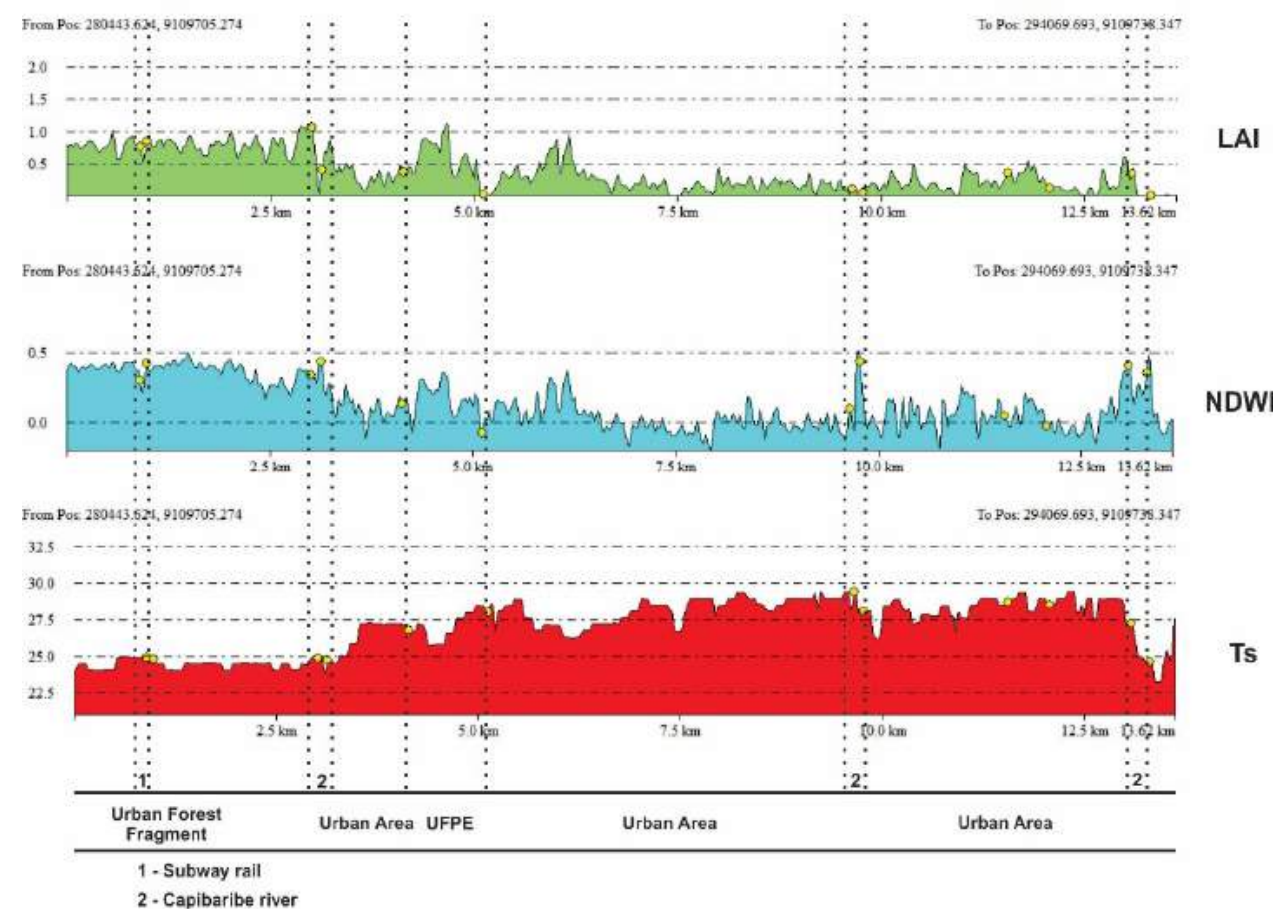

Figure 8. Representation of the linear transect 1 to the image of 28 September 1989.

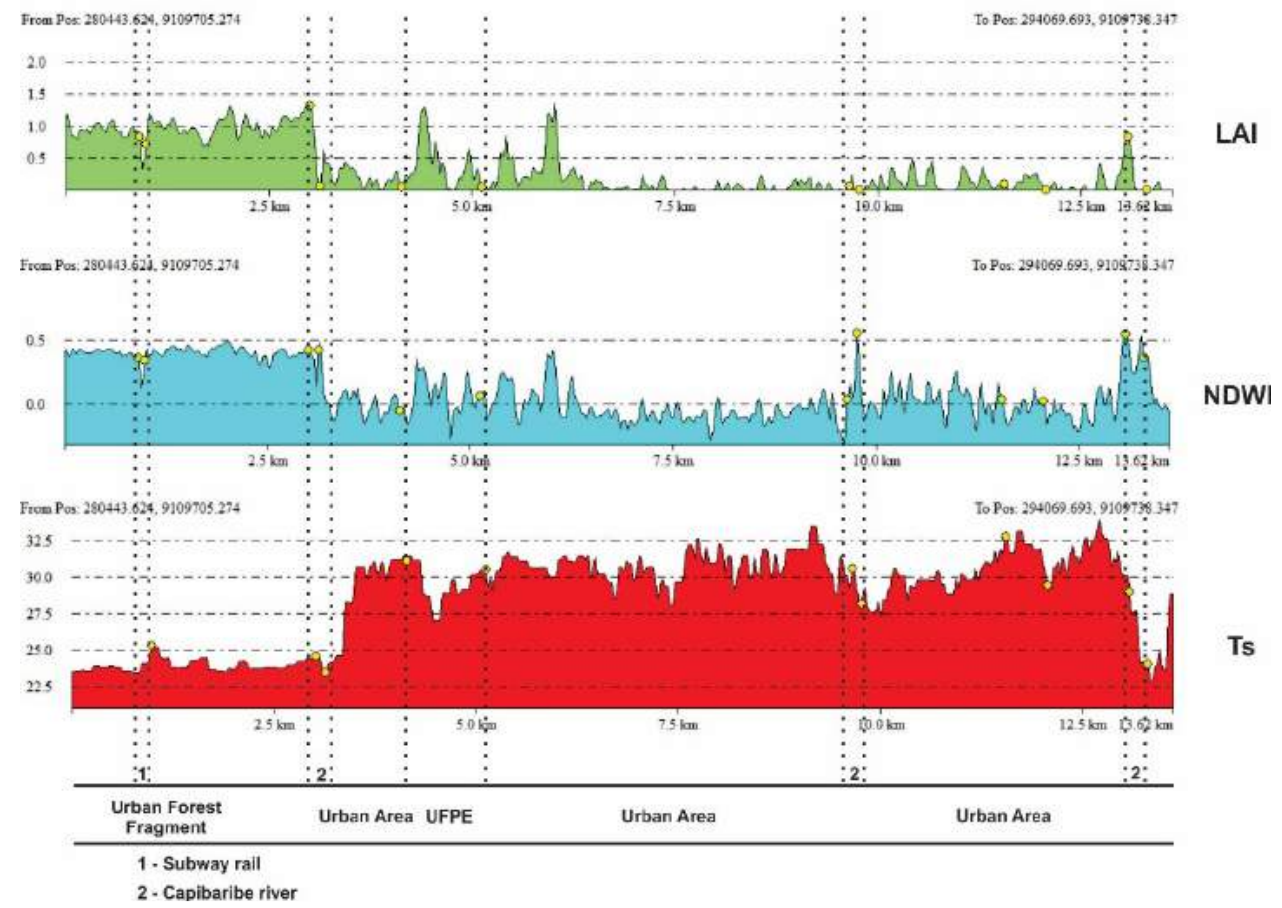

Figure 9. Representation of the linear transect 1 to the image of 26 August 2006. 


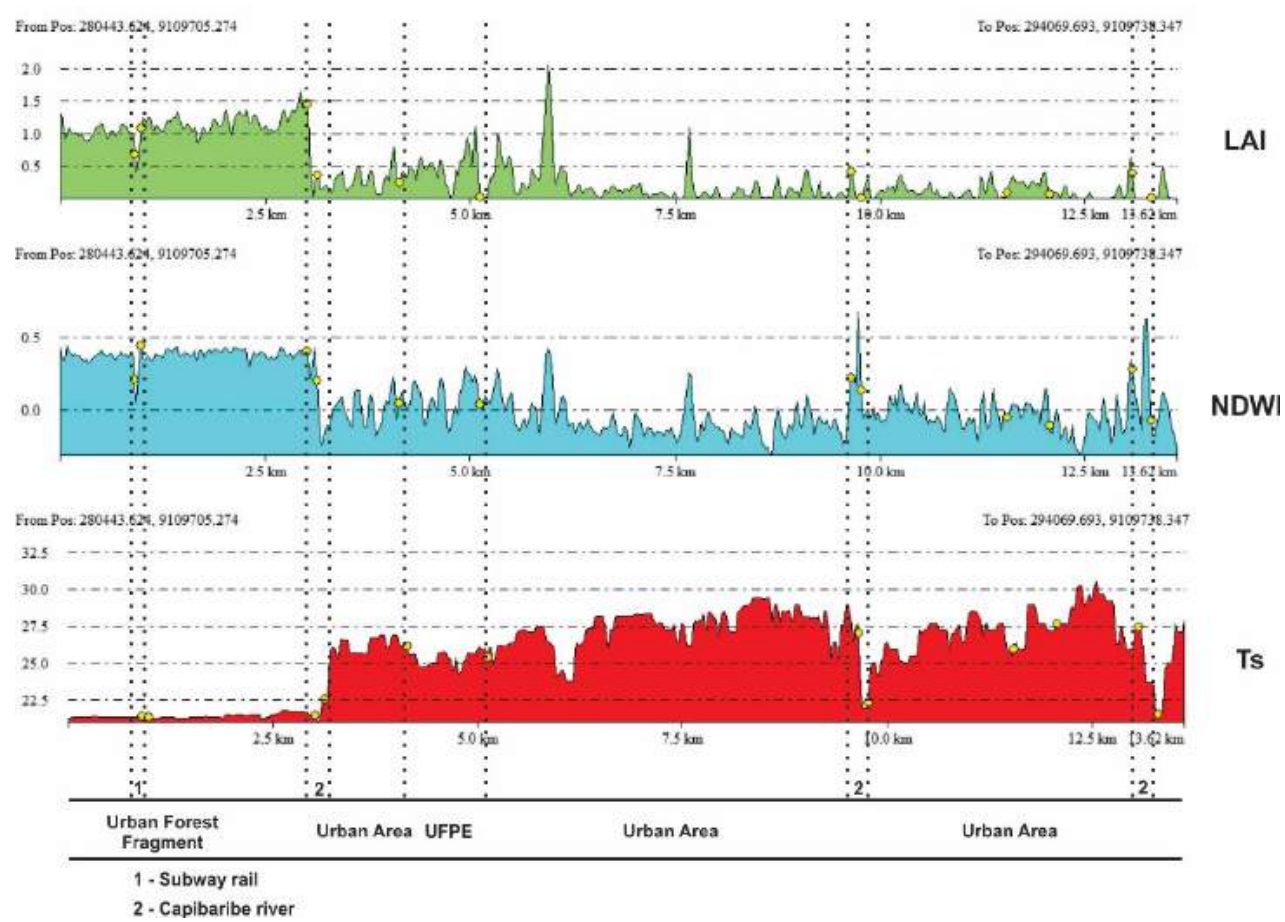

Figure 10. Representation of the linear transect 1 to the image of 6 September 2010.

Considering the linear transect 2 (Figure 11 to 13), a greater alternation of values is observed due to the greater amount of forest fragments of different sizes and various environmental conditions. The highway BR-101 currently separates the forest fragments of the Barro and Engenho Uchôa, found in this transect, present high degradation due to human actions and. The forest fragment Sítio Grande has installed in its interior an area of spontaneous occupation and industry, and the Mangrove of Pina presents greater preservation due to the guardianship of the Navy of Brazil.

However, it is also observed a marked elevation of temperature in the areas studied, while the fragments and the surrounding areas present a greater temperature softening and higher values of LAI and NDWI.

September 28, 1989

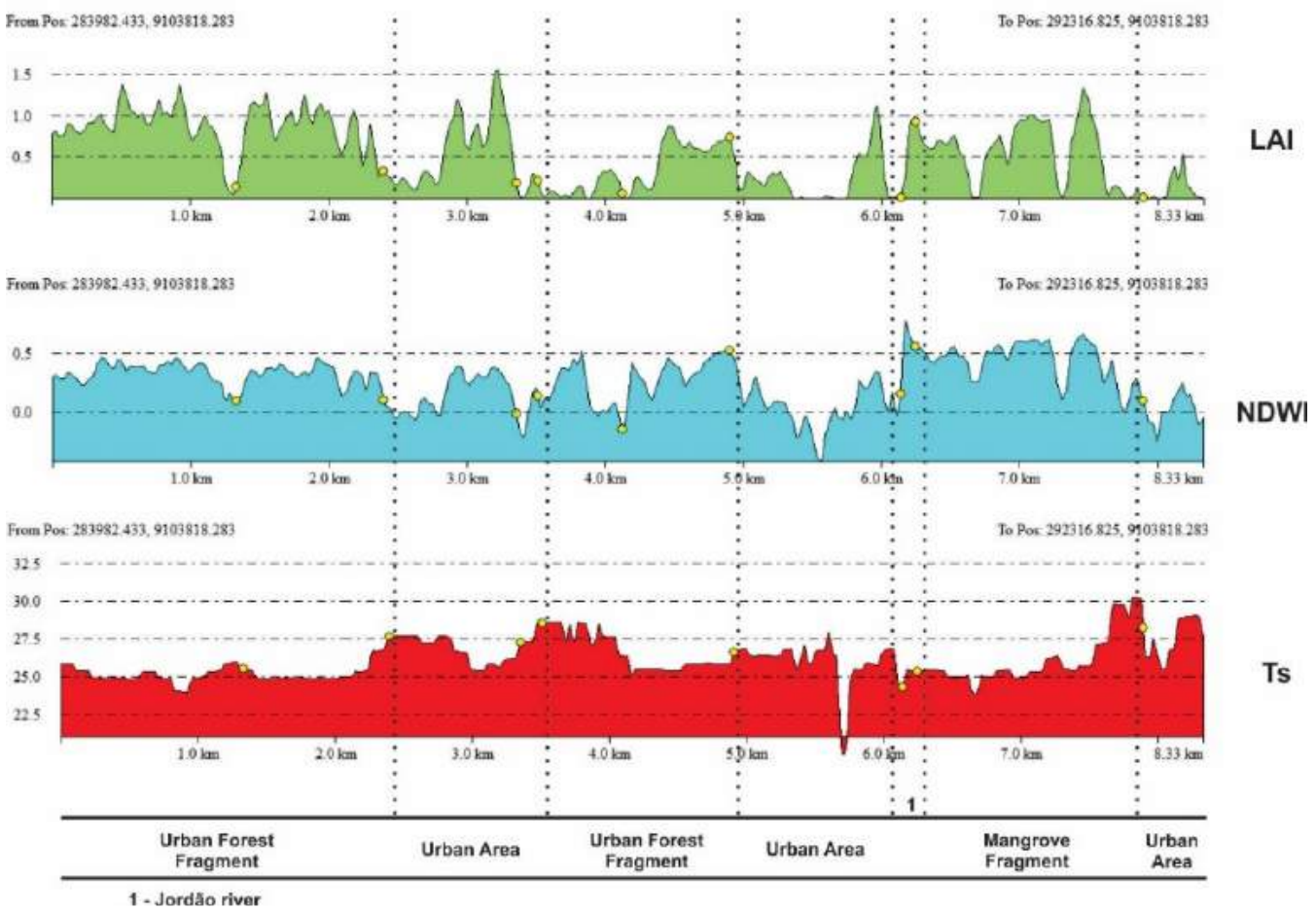

Figure 11. Representation of the linear transect 2 to the image of 28 September 1989. 


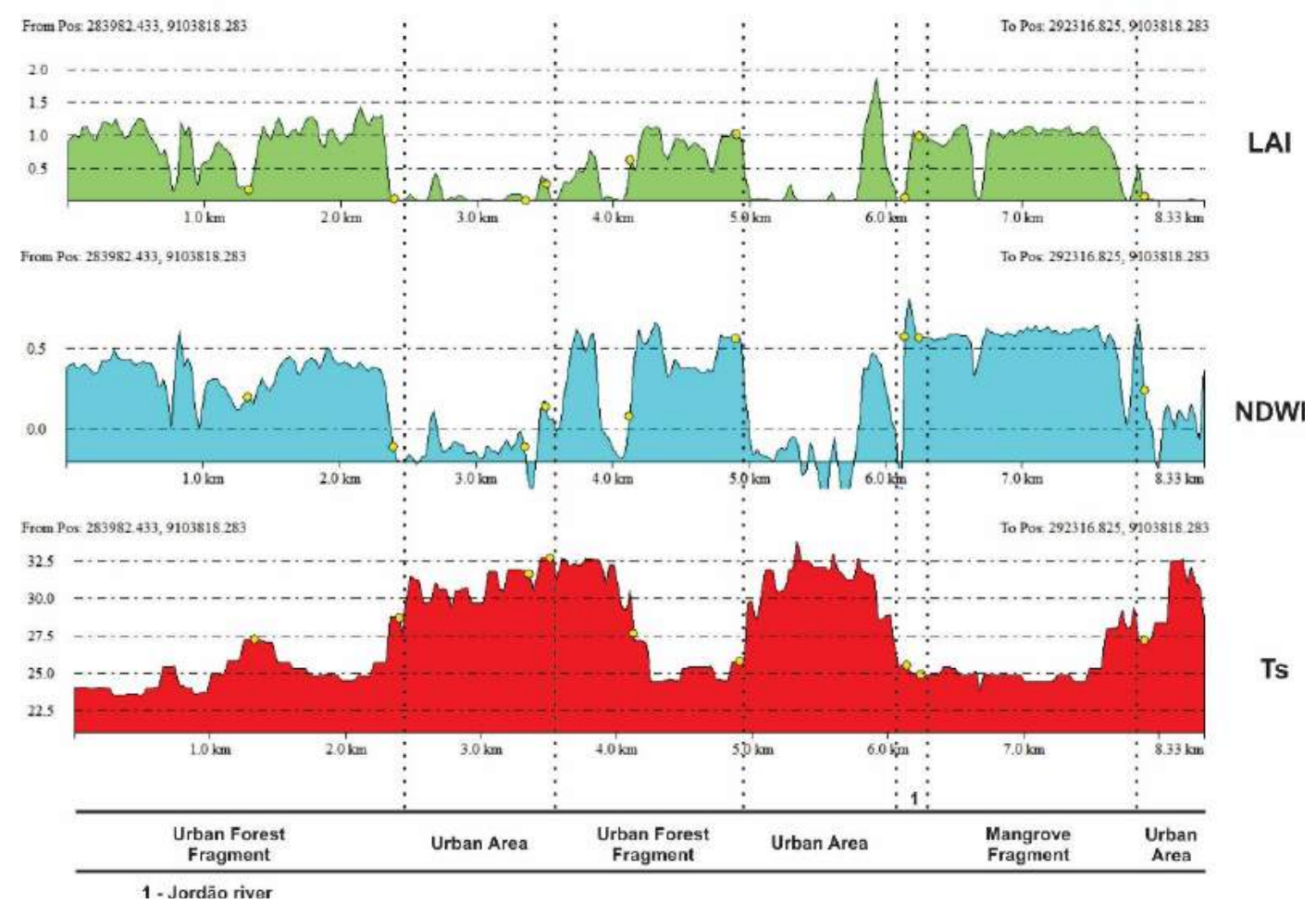

Figure 12. Representation of the linear transect 2 to the image of 26 August 2006.

September 6, 2010

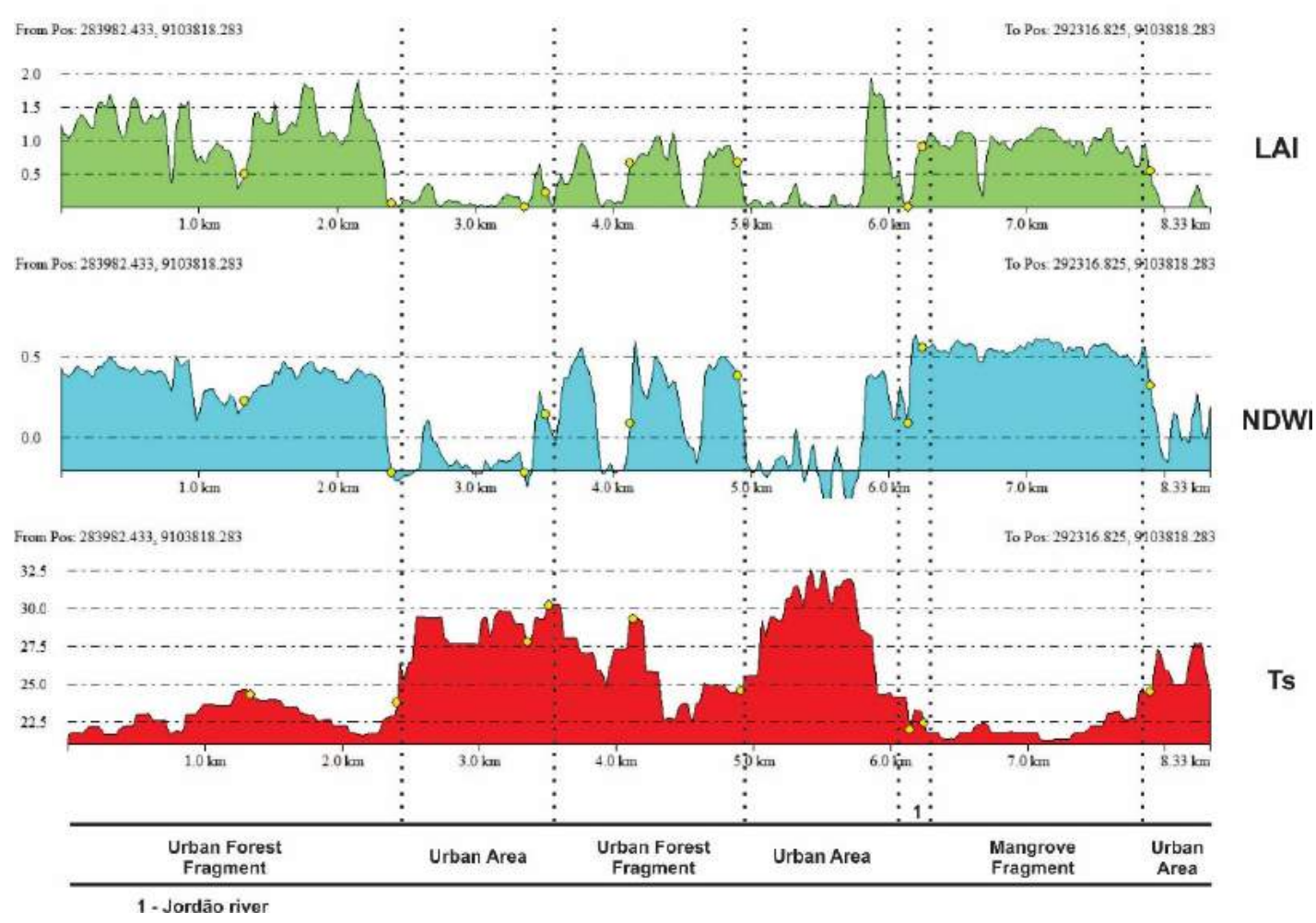

Figure 13. Representation of the linear transect 2 to the image of 6 September 2010.

\section{Discussion}

Studies carried out by several authors in several municipalities and Brazilian capitals, either by satellite image analysis or geo-referenced aerial photographs, have demonstrated a gradual decrease in the vegetation cover. It is due to, in most cases, the lack of adequate public planning or compliance with legislation (Silva et al., 2008), and to the extent that it is more likely to be associated with 
urban sprawl (Rodrigues \& Luz, 2007, Rossetti et al., 2007; Vieira et al., 2008; Machado et al., 2010).

In a study in the city of Maceió, using TM images of the Landsat satellite, Novas (2008) found association between lowest LAI values, urban areas and water bodies and, as urbanization intensified, LAI values decreased, while the areas of native vegetation presented the highest values, corroborating the results of this study.

Braga et al. (2009), in a study near to Quixeré-CE, found high LAI values (ranging from 1.2 to 2.4 ) in areas with higher native vegetation and irrigated agriculture. Cardozo et al. (2009), in a study in the Pantanal region - in the orbit point 226-73 of the Landsat TM sensor, verified that lowest NDWI were associated with areas with a predominance of soil, while the highest values were associated with areas with a high predominance of water, corroborating the results of Oliveira et al. (2010) in a study in the hydrographic basin of the Moxotó River, in a semi-arid environment of the Brazilian Northeast.

Holland \& Guerra (2010), in the EixoForte region, located to the west of the State of Pará, in the municipality of Santarém, found that forest areas present NDWI values oscillating between 0.60 and 0.80 . In areas with low vegetation cover or sparse vegetation (savannas, for example), the indexes varied from 0.2 to -0.4 (negative). Areas with few or almost any vegetation coverage showed that moisture index was near to -1 .

The areas surrounding large forest fragments have more favorable surface temperature values when compared to more urbanized areas. Aiming at a greater mitigation of some areas could be implanted vegetation of arboreal and herbaceous size in the streets near to these fragments that, in addition to presenting benefits for the population, would also benefit the fragments, avoiding abrupt changes in use.

Vegetated areas refresh the vicinity through evapotranspiration, promoting the conversion of solar energy into evaporated water rather than heat and lowering the vegetation and air temperature, as well as promoting shaded areas (in the case of vegetation Of Arboreal size), providing a fresher surface (Gartland, 2010).

\section{Conclusion}

It is noticeable the scarcity of vegetation cover in several areas of the city of Recife, and it is crucial to provoke an increase in the surface temperature and discomfort for the population.

The areas surrounding forest fragment areas have lower surface temperature values that could be optimized if there was an area with more tree and shrub vegetation functioning as a buffer zone.

\section{Acknowledgements}

The authors are grateful to the Conselho Nacional de Desenvolvimento Científico e Tecnológico $(\mathrm{CNPq})$ for funding the Mata e Mangue Project: 577356/2008-9, to Instituto Nacional de Pesquisas Espaciais (INPE) for the satellite images through the Satellite Image Catalog and the Universidade Federal de Pernambuco for institutional support. Grant of Productivity of CNPq to Rejane M. M. Pimentel and Josiclêda D. Galvíncio. The City Hall of Recife by the primary geo-referenced database.

\section{References}

ACCIOLY, L. J.; PACHECO, A.; COSTA, T. C. C.; LOPES, O. F.; OLIVEIRA, M. A. J. 2002. Relações empíricas entre a estrutura da vegetação e dados do sensor TM/Landsat. Revista Brasileira de Engenharia Agrícola e Ambiental, v.6, n.3, p.492-498.

ALLEN, R. G.; TASUMI, M.; TREZZA, R. 2002. SEBAL (Surface Energy Balance Algorithms for Land). Advance Training and Users Manual Idaho Implementation, version 1.0. 97p.

BERMAN, M. 1982. All that is solid melts into air: The Experience of Modernity. 1. ed. New York: Simon and Schuster. 465 p.

BASTIAANSSEN, W. G. M.; MENENTI, M.; FEDDES, R. A.; HOLTSLAG, A. A. M. A. 1998a. Remote Sensing Surface Energy Balance Algorithm for Land (SEBAL) 1. Formulation. Journal of Hydrology, v.212-213, p.198-212.

BASTIAANSSEN, W. G. M.; PELGRUM, H.; WANG, J.; MORENO, Y. M. J.; ROERINK, G. J.; VAN DER WAL, T. 1998b. The Surface Energy Balance Algorithm for Land (SEBAL) 2. Validation. Journal of Hydrology, v.212-213, p.213-229.

BOEGH, E.; SOEGAARD, H.; THOMSEN, A. 2002. Evaluating evapotranspiration rates and surface conditions using Landsat TM to estimate atmospheric resistance and surface resistance. Remote Sensing of Environment, v.79, n.1, p.329343.

BRAGA, C. C.; SOARES, F. R.; DANTAS, F. R. C.; BARBIERI, L. F. P. 2009. Determinação do albedo e índice de área foliar usando o sensor TM/LANDSAT 5. In: XIV Simpósio Brasileiro de 
Sensoriamento Remoto, Anais, Natal, Brasil, INPE, pp.935-942.

CARDOZO, F. S.; PEREIRA, G.; SILVA, G. B. S. S.; SILVA, F. B.; SHIMABUKURO, Y. E.; MORAES, E. C. 2009. Discriminação de áreas alagadas no Pantanal sul matogrossense a partir de imagens orbitais. In: $2^{\mathbf{o}}$ Simpósio de Geotecnologias no Pantanal, Anais, Corumbá, 7-11 novembro, Embrapa Informática Agropecuária/INPE, pp.99-106.

CHANDER, G.; MARKHAM, B. 2003. Revised Landsat-5 TM Radiometric Calibration Procedures and Postcalibration Dynamic Ranges. IEEE Transactions on Geoscience and Remote Sensing. v. 41. n. 11, p.2674-2677.

CHEN, X.; ZHAO, H.; LI, P.; YIN, Z. 2006. Remote sensing image-based analysis of the relationship between urban heat island and land use/cover changes. Remote Sensing of Environment, v.104, p.133-146.

DIJK, A. I. J. M.; BRUIJNZEEL, L. A. 2001. Modelling rainfall interception by vegetation of variable density using an adapted analytical model. Part 2-Model validation for a tropical upland mixed cropping system. Journal of Hydrology, v.247, p.239-62.

GAO, B. C. 1996. NDWI-A Normalized Difference Water Index for remote sensing of vegetation liquid water from space. Remote Sensing of Environment, v.58, p.257-266.

GARTLAND, L. 2010. De Ilhas de calor para comunidades frescas. In: Gatland, L. Ilhas de calor: como mitigar zonas de calor em áreas urbanas. Tradução: Gonçalves, S. H., São Paulo: Oficina de Textos.

GIONGO, P. R. 2008. Estimativa do balanço de radiação com técnicas de sensoriamento remoto e dados de superfície. Dissertação de Mestrado (Mestrado em Engenharia Agrícola) Universidade Federal Rural de Pernambuco. Departamento de Tecnologia Rural. 92f. Recife.

GUIMARÃES, H. B.; BRAGA, R. A. P.; OLIVEIRA, T. H. 2012a. Evolução da condição ambiental em fragmentos de mata atlântica na região metropolitana do Recife-PE. Revista Brasileira de Ciências Agrárias, v.7, n.2, p.306314.
GUIMARÃES, H. B.; BRAGA, R. A. P.; OLIVEIRA, T. H. 2012b. Serviços Ambientais Gerados por Matas Tuteladas ao Exército Brasileiro na Região Metropolitana no Recife. Revista Floresta e Ambiente, v.19, n.3, p.362-373.

HOLANDA, A. S. S.; GUERRA, C. E. 2010. Monitoramento da vegetação da região do eixoforte no município de Santarém-PA utilizando imagens dos índices de vegetação NDVI e NDWI. In: III Simpósio Brasileiro de Ciências Geodésicas e Tecnologias da Geoinformação. Anais, pp.1-5.

HUETE, A. R. 1988. Adjusting vegetation indices for soil influences. International Agrophysics, v.4, n.4, p.367-376.

INSTITUTO POLIS. 2009. Moradia é central: inclusão, acesso e direito a cidade-Recife. Disponível em: http://www.moradiacentral. org.br/pdf/recife.pdf.

LANG, A. R. G.; MCMURTRIE, R. E. 1992. Total leaf areas of single trees of Eucalyptus grandis estimated from transmittances of the sun's beam. Agricultural and Forest Meteorology, v.58, p.7992.

KERGOAT, L. 1998. A model for hydrological equilibrium of leaf area index on a global scale. Journal of Hydrology, v.212-13, p.268-86.

KÖPPEN, W. 1948. The Climates of Nort America. R. Handbuch der Klimatologie, Berlim.

MACHADO, R. R. B.; PEREIRA, E. C. G.; ANDRADE, L. H. C. 2010. Evolução temporal (2000-2006) da cobertura vegetal na zona urbana do município de Teresina-Piauí-Brasil. Revista da Sociedade Brasileira de Arborização UrbanaREVSBAU, v.5, n.3, p.97-112.

MARKHAM, B. L.; BARKER, L. L. 1987. Thematic mapper bandpass solar exoatmospherical irradiances. International Journal of Remote Sensing, v.8, n.3, p.517-523.

NOVAS, M. F. B. 2008. Mapeamento das estimativas do saldo de radiação e índices de vegetação em área do estado de Alagoas com base em sensores remotos. Dissertação de mestrado em Meterorologia (UFAL). 158f.

OLIVEIRA, T. H.; MACHADO, C. C. C.; SILVA, J. S.; GALVÍNCIO, J. D.; PIMENTEL, R. M. M.; SILVA, B. B. 2010. Índice de Umidade (NDWI) e Análise Espaço-Temporal do Albedo da Superfície 
da Bacia Hidrográfica do Rio Moxotó-PE. Revista Brasileira de Geografia Física, v.3, p.55-69.

OLIVEIRA, T. H. 2012. Mudança espaço temporal do uso e cobertura do solo e estimativa do balanço de energia e evapotranspiração diária no município do Recife-PE. Dissertação (mestrado)Universidade Federal de Pernambuco. CFCH. Programa de Pós-Graduação em Geografia. 154f. :il., $30 \mathrm{~cm}$.

PAIVA, Y. G.; RIBEIRO, A.; ALMEIDA, A. Q.; GLERIANE, J. M.; PEZZOPANE, J. E. M. 2009. Estimativa do Índice de Área Foliar (IAF) através de Fotografias Hemisféricas e Índices de Vegetação em plantios clonais de Eucalipto. In: XIV Simpósio Brasileiro de Sensoriamento Remoto, Natal, Brasil, 25-30 abril, INPE, pp.28732880.

RIBEIRO, M. T.; RAMOS, F. N.; SANTOS, F. A. M. 2009. Tree structure and richness in an Atlantic Forest fragment: distance from anthropogenic and natural edges. Revista Árvore, v.33, n.6, p.11231132.

RODRIGUES, J. E. C.; LUZ, L. M. 2007. Mapeamento da cobertura vegetal da Área Central do município de Belém PA, através de sensores remotos de base orbital (sensor TM, LANDSAT 5 e sensor CCD, CBERS 2). In: XIII Simpósio Brasileiro de Sensoriamento Remoto, Florianópolis, Brasil, INPE, pp.1063-1070.

ROSSETTI, L. A. F. G.; PINTO, S. A. F.; ALMEIDA, C. M. 2007. Geotecnologias aplicadas à caracterização das alterações da cobertura vegetal intra-urbana e da expansão urbana da cidade de Rio Claro (SP). In: XIII Simpósio Brasileiro de Sensoriamento Remoto, Florianópolis, Brasil, INPE, pp.5479-5486.

SELLERS, P. J.; DICKINSON, R. E.; RANDALL, D. A.; BETTS, A. K.; HALL, F. G.; BERRY, J. A.;
COLLATZ, G. J.; DENNING, A. S.; MOONEY, H. A.; NOBRE, C. A.; SATO, N.; FIELD, C. B.; HENDERSON-SELLERS, A. 1997. Modeling the exchanges of energy, water, and carbon between continents and the atmosphere. Science, v.275, p.502-509.

SILVA, B. B.; CÂNDIDO, M. V. 2004. Determinação da evapotranspiração em escala regional através do SEBAL e imagens Landsat 5TM. Anais do XIII Congresso Brasileiro de Meteorologia, Fortaleza.

SILVA, B. B. da; LOPES, G. M.; AZEVEDO, P. V. de. 2005. Balanço de radiação em áreas irrigadas utilizando imagens Landsat 5-TM. Revista Brasileira de Meteorologia, v.20, n.2, p.243-252.

TEIXEIRA, A. H. de C.; BASTIAANSSEN, W. G. M.; AHMAD, M. D.; BOS, M. G. 2009. Reviewing SEBAL input parameters for assessing evapotranspiration and water productivity for the Low-Middle São Francisco River basin, Brazil Part B: Application to the regional scale. Agricultural and Forest Meteorology, v.149 p.477-490.

XAVIER, A. C.; VetToraZZI, C. A. 2004. Monitoring leaf area index at watershed level Through NDVI from LANDSAT-7/ETM+ data. Sci. Agric., v.61, n.3, p.243-252.

VIEIRA, C. H. S. D.; BIONDI, D. 2008. Análise da dinâmica da cobertura vegetal de Curitiba, PR (de 1986 a 2004), utilizando imagens Landsat TM. Revista Árvore, v.32, n.3, p. 479-487.

ZENG, H.; PELTOLA, H.; VAISANEN, H.; KELLOMAKI, S. 2009. The effects of fragmentation on the susceptibility of a boreal forest ecosystem to wind damage. Forest Ecology and Management, v.257, p.1165-1173. 